\title{
The transfer of the Malagasy species of Strobilanthes Blume to Acanthopale C. B. Clarke (Acanthaceae)
}

\author{
Martin W. Callmander \& Peter B. Phillipson
}

\begin{abstract}
CALLMANDER, M. W. \& P. B. PHILLIPSON (2015). The transfer of the Malagasy species of Strobilanthes Blume to Acanthopale C. B. Clarke (Acanthaceae). Candollea 70: 253-256. In English, English and French abstracts. DOI: http://dx.doi.org/10.15553/c2015v702a12

Five Acanthaceae species originally described in the genus Strobilanthes Blume are formally transferred to the genus Acanthopale C. B. Clarke, following currently accepted generic delimitation in the family. The necessary combinations: Acanthopale breviceps (Benoist) Callm. \& Phillipson, Acanthopale cuneifolia (Benoist) Callm. \& Phillipson, Acanthopale bumblotii (Benoist) Callm. \& Phillipson, Acanthopale perrieri (Benoist) Callm. \& Phillipson and Acanthopale ramiflora (Benoist) Callm. \& Phillipson are established.
\end{abstract}

\section{Résumé}

CALLMANDER, M. W. \& P. B. PHILLIPSON (2015). Transfert des espèces malgaches de Strobilanthes Blume à Acanthopale C. B. Clarke (Acanthaceae). Candollea 70: 253-256. En anglais, résumés anglais et français. DOI: http://dx.doi.org/10.15553/c2015v702a12

Cinq espèces d'Acanthaceae décrites dans le genre Strobilanthes Blume sont formellement transférées dans le genre Acanthopale C. B. Clarke, en accord avec les délimitations génériques qui prévalent actuellement dans la famille. Les nouvelles combinaisons nécessaires: Acanthopale breviceps (Benoist) Callm. \& Phillipson, Acanthopale cuneifolia (Benoist) Callm. \& Phillipson, Acanthopale humblotii (Benoist) Callm. \& Phillipson, Acanthopale perrieri (Benoist) Callm. \& Phillipson and Acanthopale ramiflora (Benoist) Callm. \& Phillipson sont établies.

\section{Keywords}

ACANTHACEAE - Acanthopale - Strobilanthes - New combinations - Madagascar

\footnotetext{
Addresses of the authors:

MWC: Missouri Botanical Garden, P.O. Box 299, St. Louis, MO, 63166-0299, U.S.A. Currently at: Conservatoire et Jardin botaniques de la Ville de Genève, C.P. 60, 1292 Chambésy, Genève. Switzerland. E-mail: martin.callmander@ville-ge.ch

PBP: Missouri Botanical Garden, P. O. Box 299, St. Louis, MO, 63166-0299, U.S.A. and Institut de Systématique, Évolution, et Biodiversité (UMR 7205 - CNRS MNHN EPHE UPMC), Muséum national d'Histoire naturelle, C.P. 39, rue Cuvier 57, 75231 Paris CEDEX 05, France.
} 


\section{Introduction}

Phylogenetic studies have greatly improved our understanding of the large family Acanthaceae (McDADE et al., 2000 and references herein) and were discussed in the last comprehensive review of the generic level taxonomy of the family by Scotland \& Vollesen (2000). Several major well-supported phylogenetic lineages have been revealed and these have been discussed on the basis of morphological and molecular evidence. Expanded investigations have subsequently permitted the delimitation and generic circumscriptions within certain tribes to be further refined, such as in the case of the largest of these, the Ruellieae Nees (c. 1200 spp.) (Tripp, 2007; Tripp et al., 2009; TRIPP et al., 2013). The Ruellieae is well-represented in Madagascar, and while some of the necessary nomenclatural changes following the revised generic circumscription have already been effected (CAllmander et al., 2014; Tripp, 2007; Tripp et al., 2013), others require further investigation.

Clarke (1899) described the genus Acanthopale C. B. Clarke in his treatment of the Acanthaceae for "Flora of Tropical Africa" to accommodate all the African species formerly included in Strobilanthes Blume, from which it differed notably in pollen morphology. BENOIST (1939) retained in the latter genus the only species of this group previously known from Madagascar, S. madagascariensis Baker, and described two new species. However, $S$. madagascariensis (but not the other species) was later transferred to Acanthopale by Breme kamp (1943), who described additional species from Continental Africa and argued that the two genera are distinct. Benorst $(1945,1946,1947)$ nevertheless continued to regard the two genera as synonyms and described six additional species and one variety from Madagascar in Strobilanthes. One of these species, $S$. gracilicaulis Benoist, was later transferred to the genus Dyschoriste Nees (Benoist, 1967).

A pragmatic approach to the systematics of Strobilanthes has been adopted recently and provides geographical, morphological and molecular phylogenetic coherence (CARINE \& Scotland, 2002; Moylan et al., 2004). This approach has been adopted in all recent taxonomic revisions (e.g., Wood \& Scootland, 2003, 2006, 2009; Deng et al., 2006, 2010). The genus Strobilanthes as currently defined includes more than 450 spp. and is distributed from South Asia to Northern Australia through Southeast Asia and Malesia (Moylan et al., 2004), whereas Acanthopale is restricted to Africa and Madagascar (Bremekamp, 1943, 1944; Scotland \& Vollesen, 2000; Tripp et al., 2013).

In the course of reviewing the genera of Acanthaceae for the "Catalogue of the Vascular Plants of Madagascar" (Madagascar Catalogue, 2015), we noticed that only a single species of Strobilanthes from Madagascar had an available combination in Acanthopale, despite the general acceptance that the genus Strobilanthes is absent from Africa and
Madagascar. For the preparation of this note we examined all of the material cited by BENoIsT (1967) as well as additional collections known from Madagascar and deposited at $G, K$, $\mathrm{MO}$ and $\mathrm{P}$, mostly more recent, and reviewed the eight species of Strobilanthes that he recognised in the Flora. In this note we establish the five necessary new combinations for the Malagasy species recognized in Strobilanthes by BenoIst (1967) and place two species and one variety in synonymy. We also provide brief explanatory observations for certain species, and a full list of specimens examined and distribution maps for all the accepted species of Acanthopale can be found in the Madagascar Catalogue (2015).

Recent taxonomic treatment for Continental Africa accepts 6 to 8 species (Vollesen, 2008), and the 6 species accepted here for Madagascar therefore nearly double the number of species in the genus. A complete revision of the genus may reveal that certain African and Malagasy species should be regarded as synonyms, but will also likely reveal new species endemic to Madagascar. TRIPP (2007) has suggested that two Malagasy species currently placed in Ruellia L. with echinate pollen grains (typically coarsely reticulate in Ruellia) may also be better included in Acanthopale: Ruellia cyanea Benoist and $R$. dissidens Benoist. Further taxonomic and molecular work is needed to determine the systematic position of these two species and indeed to fully understand the diversity of the genus in Madagascar as a whole and its relation with the African species. A complete revision of Acanthopale is clearly needed (see also Clarke, 1899; Vollesen, 2008).

\section{Nomenclature}

Acanthopale breviceps (Benoist) Callm. \& Phillipson, comb. nova.

$\equiv$ Strobilanthes breviceps Benoist in Not. Syst. (Paris) 12: 7. 1945.

Typus: Madagascar. Prov. Toamasina: sur la rivière Anova, c. 200 m, IX.1912, Perrier de la Bâthie 9460 (holo-: P [P00089257]!; iso-: P [P00089258]!).

Acanthopale cuneifolia (Benoist) Callm. \& Phillipson, comb. nova.

$\equiv$ Strobilanthes cuneifolia Benoist in Not. Syst. (Paris) 12: 6. 1945.

Typus: Madagascar. Prov. Antsiranana: Massif du Tsaratanana, 1700 m, XII.1923, Perrier de la Bâthie 15270 (holo-: P [P00089259]!; iso-: K [K000394193]!, P [P00089260, P00089261]!).

= Strobilanthes mediocris Benoist in Not. Syst. (Paris) 12: 8. 1945. Typus: Madagascar. Prov. Antsiranana: Massif du Tsaratanana, c. 2000 m, I.1923, Perrier de la Bâthie 15589 (holo-: P [P00089272]!). 
Observations. - Strobilanthes cuneifolia and S. mediocris were described from the same locality in the Tsaratanana massif in north-eastern Madagascar. The two taxa have been segregated on the basis of the presence of trichomes on the sepals "au moins dans la partie terminale" in S. mediocris and their absence in S. cuneifolia: (Benoist, 1967: 98). Examination of the herbarium collections available now shows that this character is not clear-cut and we therefore prefer to recognize a one species at mid to high elevation in the Tsaratanana and Manongarivo massifs and further north in Montagne d'Ambre.

Acanthopale humblotii (Benoist) Callm. \& Phillipson, comb. nova.

$\equiv$ Strobilanthes humblotii Benoist in Not. Syst. (Paris) 13: 13. 1947.

Typus: Madagascar. Prov. Toamasina: sine loc., s.d., Humblot 444 (holo-: P [P0089266]!; iso-: K [K000394192]!, P [P0089265]!).

Acanthopale perrieri (Benoist) Callm. \& Phillipson, comb. nova.

$\equiv$ Strobilanthes perrieri Benoist in Not. Syst. (Paris) 8: 145.1939.

Typus: MADAgascar. Prov. Mahajunga: bois sablonneux Ankaladina sur la Betsiboka (Boeny), VI.1902, Perrier de la Bâthie 9441 (holo-: P [P00089273]!; iso-: P [P00089274, P00089275]!).

Acanthopale ramiflora (Benoist) Callm. \& Phillipson, comb. nova.

$\equiv$ Strobilanthes ramiflora Benoist in Not. Syst. (Paris) 12: 7. 1945.

Typus: Madagascar. Prov. Antanarivo: Mt. Angavokely, 1450 m, III.1924, Perrier de la Bâtbie 16075 (holo-: P [P00089276]!; iso-: P [P00089277, P00089278]!).

$=$ Strobilanthes curviflora Benoist in Not. Syst. (Paris) 12: 6. 1945. Typus: Madagascar. Prov. Toamasina: Massif de l'Andrangovalo au SE du lac Alaotra, Zahamena RN, c. 1200 m, X.1937, Humbert E Cours 17951 (holo-: P [P00089262]!; iso-: K [K000394187, K000394188]!, P [P00089263, P00089264]!).

$=$ Strobilanthes madagascariensis var. calvescens Benoist in Not. Syst.(Paris) 12:138.1946. Typus: MADAGASCAR. Prov. Fianarantsoa: bois humide de la rivière Raimany, bords du Matitana, 700 m, IX.1910, Perrier de la Bâthie 9475 (holo-: P [P00089269]!; iso-: P [P00089270, P00089271]!).
Observations. - Strobilanthes ramiflora and S. curviflora were distinguished on the basis of the shape and the pubescence of the bracts and on the number of flowers of the inflorescences (Benoist, 1956, 1967). Those characters vary in the collections now available and we currently prefer to recognize a single taxon. Strobilanthes madagascariensis var. calvescens has been segregated on the basis of a single collection (Perrier de la Bâthie 9475) due to the sparser pubescence on its bracts and sepals. However, in our opinion, this collection matches Acanthopale ramiflora very well. We therefore recognize only one species at mid elevation $(700-1200 \mathrm{~m})$ in the highlands and eastern region of Madagascar.

\section{References}

Benoist, R. (1939). Nouvelles Acanthacées malgaches. Notul. Syst. (Paris) 8: 135-161.

Benoist, R. (1945). Descriptions de nouvelles Acanthacées malgaches. Notul. Syst. (Paris) 12: 1-16.

Benoist, R. (1946). Nouvelles Acanthacées africaines et malgaches. Notul. Syst. (Paris) 12: 137-146

Benoist, R. (1947). Nouvelles Acanthacées de Madagascar. Notul. Syst. (Paris) 13: 1-13

Benoist, R. (1967). Acanthacées. In: Humbert, H. (ed.), Fl. Madagascar Comores 182(1).

Bremeramp, C. E. B. (1943). Ueber Dischistocalyx T. And. ex Bth. und Acanthopale C. B. Clarke (Acanthaceae). Bot. Jahrb. Syst. 73: 126-150.

Bremekamp, C. E. B. (1944). Materials for a monograph of the Strobilanthinae (Acanthaceae). Verb. Kon. Ned. Akad. Wetensch., Afd. Natuurk., Tweede Sect. 41: 1-305.

Callmander, M. W., E. A. Tripp \& P. B. Phillipson (2014). A new name in Ruellia L. (Acanthaceae) for Madagascar. Candollea 69: 81-83.

Carine, M. A. \& R. W. Scotland (2002). Classification of Strobilanthinae (Acanthaceae): Trying to classify the unclassifiable? Taxon 51: 259-279.

Clarke, C. B. (1899). Acanthopale. In: Thiselton-Dyer, W. T. (ed.), Fl. Trop. Africa 5: 62-65.

Deng, Y. F., J. R. I. Wood \& R. W. Scotland (2006). New and reassessed species of Strobilanthes (Acanthaceae) in the Flora of China. Bot. J. Linn. Soc. 150: 369-390.

Deng, Y. F., J. R. I. Wood \& C. M. Gao (2010). New species and new combinations of Strobilanthes Blume (Acanthaceae) from China. J. Trop. Subtrop. Bot. 18: 469-484.

McDade, L. A., S. E. Masta, M. L. Moody \& E. Waters (2000). Phylogenetic relationships among Acanthaceae: evidence from two genomes. Syst. Bot. 25: 106-121. 
Madagascar Catalogue (2015). Catalogue of the Vascular Plants of Madagascar. Missouri Botanical Garden, St. Louis \& Antananarivo [http://www.efloras.org/madagascar].

Moylan, E. C., J. R.Bennett, M. C. Carine, R. G. Olmstead \& R. W. Scotland (2004). Phylogenetic relationships among Strobilanthes s.l. (Acanthaceae): evidence from ITS nrDNA, trnL-F cpDNA, and morphology. Amer. J. Bot. 91: 724-735.

Scotland, R. W. \& K. Vollesen (2000). Classification of Acanthaceae. Kew Bull. 55: 513-589.

Tripp, E. A. (2007). Evolutionary relationships within the speciesrich genus Ruellia (Acanthaceae). Syst. Bot. 32: 628-649.

Tripp, E. A., T. F. Daniel, S. Fatimah \& L. A. McDade (2013). Phylogenetic Relationships within Ruellieae (Acanthaceae) and a Revised Classification. Int. J. Plant Sci. 174: 97-137.

Tripp, E. A., T. F. Daniel, J. C. Lendemer \& L. A. McDade (2009). New molecular and morphological insights prompt transfer of Blechum to Ruellia (Acanthaceae). Taxon 58: 893-906.

Vollesen, K. (2008). Acanthopale. In: Beentje, H. J. \& S. A. Ghazanfar (ed.), Fl. Trop. E. Africa, Acanthaceae, part 1: 214-219.

Wood, J. R. I. \& R.W. Scotland (2003). The 2-lipped species of Strobilanthes (Acanthaceae). Kew Bull. 58: 83-129.

Wood, J. R. I. \& R.W. Scotland (2006). Some notes on the Strobilanthes penstemonoides (Acanthaceae) complex in China, India and South East Asia. Kew Bull. 61: 5-16.

Wood, J. R. I. \& R. W. Scotland (2009). New and little-known species of Strobilanthes (Acanthaceae) from India and South East Asia. Kew Bull. 64: 3-47. 